九州大学学術情報リポジトリ

Kyushu University Institutional Repository

Comparison of Adsorption Capacity of Heavy Metals between Alluvial Soils and Grey Degraded Soils in Hanoi, Vietnam

Bui, Thi Phuong Loan

Nguyen, Quang Hai

Egashira, Kazuhiko

Faculty of Agriculture, Kyushu University

https://doi.org/10.5109/9349

出版情報：九州大学大学院農学研究院紀要. 52 (2)，pp. 395-400，2007-10-29. Faculty of Agriculture, Kyushu University

バージョン：

権利関係 : 


\title{
Comparison of Adsorption Capacity of Heavy Metals between Alluvial Soils and Grey Degraded Soils in Hanoi, Vietnam
}

\author{
BUI Thi Phuong Loan', NGUYEN Quang Hai ${ }^{2}$ and Kazuhiko EGASHIRA*
}

\author{
Laboratory of Soil Science, Division of Soil Science and Plant Production, \\ Department of Plant Resources, Faculty of Agriculture, \\ Kyushu University, Fukuoka 812-8581, Japan \\ (Received June 7, 2007 and accepted July 17, 2007)
}

\begin{abstract}
Two surface soil samples were collected from each of alluvial soils and grey degraded soils in Hanoi City, Vietnam and subjected to soil chemical and physical analyses and to a batch adsorption test for evaluation of the adsorption capacity of heavy metals such as $\mathrm{Cu}, \mathrm{Pb}, \mathrm{Zn}$ and $\mathrm{Cd}$. The results showed that the alluvial soil had the high organic matter, free iron oxides, clay and active 2:1-type silicate minerals contents, and high $\mathrm{pH}$ value in comparison with those of the grey degraded soil. The adsorption isotherm of heavy metals by the soils was well fitted to the Freudlich model. The adsorbents for heavy metals as a total of organic matter, free iron oxides, and clay minerals in terms of both amount (clay content) and type (clay mineralogical composition) were larger for the alluvial soil than for the grey degraded soil. As a result, the adsorption capacity of heavy metals was distinctly higher for the former than for the latter. Within a soil, the adsorption capacity was decreased in the sequence of $\mathrm{Pb}>>\mathrm{Cu}>\mathrm{Zn}$ for the alluvial soil and of $\mathrm{Pb}>>\mathrm{Zn}>\mathrm{Cu}$ for the grey degraded soil.
\end{abstract}

\section{INTRODUCTION}

Hanoi is one of the biggest and most advanced cities in Vietnam. The rapid industrialization and motorization throughout the city, and the intensive cultivation in the sub-urban areas, in the positive side, have contributed largely to the regional or national socio-economic development. On the other hand, those have put the city under severe environmental problems including soil pollution by heavy metals. Nguyen (2006) stated that soils from industrial zones of Donganh, Gialam and Socson Districts (Hanoi suburb) were polluted by heavy metals due to discharge of untreated wastes from nearby factories. In some areas, accumulation of heavy metals in agricultural soils was considered as a consequence of application of large amounts of chemical fertilizers, agricultural chemicals and organic amendments (Nguyen and Duong, 2004; Ha and Pham, 2005). Ho and Egashira (2000) reported that sediments of the rivers flowing through industrialized and densely-populated areas of Hanoi City were polluted with various heavy metals. They mentioned that heavy metals might be accumulated in agricultural soils by applying those river/canal sediments as an organic fertilizer to keep soil fertile. Nguyen et al. (2006) predicted that under the accumulation rate as recorded recently, the heavy metal concentration in soils of Hanoi City would reach the maximum allowable level of the Vietnamese standard within next few decades.

\footnotetext{
1 Department of Soil Environmental Research, Soils and Fertilizers Institute, Dongngac, Tuliem, Hanoi, Vietnam Study-leave to Faculty of Agriculture, Kyushu University

${ }^{2}$ Laboratory of Soil Science, Division of Soil Science and Plant Production, Department of Plant Resources, Graduate School of Bioresource and Bioenvironmental Sciences, Kyushu University

* Corresponding author (E-mail: kegashi@agr.kyushu-u.ac.jp)
}

Concerning the accumulation of heavy metals, adsorption is considered a major process or a most important mechanism for controlling the metal concentration in soil. Heavy metals are bound to various soil components, of which the most important ones are organic matter, free iron oxides, and clay minerals. Therefore, different soils would have different adsorption capacities of a heavy metal. The main soil types in Hanoi City are alluvial soils and grey degraded soils which are normally found in an associated distribution with each other (Fig. 1). In reference to alluvial soils, the fertility of grey degraded soils has been recognized to decline in terms of chemical and physical properties (VSSS, 1996; NISF and DSTPQ, MARD, 2002) and clay mineralogy (Do et al., 2002; Nguyen et al., 2006). Accompanied with the soil fertility decline, adsorption capacity of heavy metals would be expected to be decreased in grey degraded soils. If this is the case, heavy metals are hardly accumulated and held in soil but are leached away to groundwater in the grey degraded soil area, leading to the spread of heavy metals to the environment which would raise difficulties for remediation after pollution.

The purposes of the present study are: (1) to compare the adsorption capacity of heavy metals between alluvial soils and grey degraded soils in Hanoi, Vietnam; and (2) to characterize the adsorption capacity of heavy metals of the soils in relation to heavy metal attributes and composition of adsorbing soil components.

\section{MATERIALS AND METHODS}

\section{Soil samples and sampling locations}

Figure 1 shows locations of sampling sites on the soil map of Vietnam. The mapped area covers the entire Hanoi City. The main soil types shown in the map are alluvial soils of the Red River system composed of sediments from the Red River and the upper stream of the 
Duong River, grey degraded soils derived from old alluvium of the Red River system, and ferralitic soils. One surface soil sample representing alluvial soils of the Red River system was collected in Minhkhai Commune, Tuliem District and another surface soil sample representing grey degraded soils was collected in Phuminh Commune, Socson District. Both soil types have been used as paddy and recently subjected to cultivation of cash crops or rice-cash crops.

Soil samples were taken at a depth of 0 to $15 \mathrm{~cm}$, air-dried and gently ground to pass through a $2-\mathrm{mm}$ sieve, before export to Japan. Chemical, physical and mineralogical properties of the soils and adsorption of heavy metals by them were examined in Kyushu University, Japan.

\section{Procedures for chemical, physical and mineralogi- cal analyses}

The $\mathrm{pH}\left(\mathrm{H}_{2} \mathrm{O}\right)$ was measured in the suspension having a soil/water ratio of $1 / 2.5$ by a $\mathrm{pH}$ meter. Organic carbon was measured by the dry combustion method using a total organic carbon analyzer and multiplied by the coefficient of 1.724 to give the organic matter content. Free iron oxides were digested by shaking with sodium hydrosulfite powder and citrate solution (Egashira et al., 2002) and the concentration of iron in the digest was determined by an atomic absorption spectrophotometer.

In the particle-size analysis, organic matter was first removed by treatment with hot $7 \% \mathrm{H}_{2} \mathrm{O}_{2}$. The sample was then dispersed by an ultrasonic vibration, and adjusted to the $\mathrm{pH} 10$ by addition of appropriate amounts of $1 \mathrm{M} \mathrm{NaOH}$. The whole $<2 \mu$ m clay fraction was separated by repeated sonification-sedimentationsiphoning with an intermittent $\mathrm{pH}$ adjustment. The whole $2-20 \mu \mathrm{m}$ silt fraction was separated by repeated sedimentation and siphoning, followed by separation of the 20-200 and $200-2,000 \mu \mathrm{m}$ sand fractions by wet-sieving. After oven-drying at $105^{\circ} \mathrm{C}$, each fraction was weighed to calculate the particle-size distribution of a soil.

The $<2 \mu$ m clay fraction separated in the particlesize analysis was used to determine the clay mineralogical composition by the X-ray diffraction (XRD) method (Do et al., 2002; Nguyen and Egashira, 2005b). Parallel-oriented samples saturated with $\mathrm{Mg}$ and $\mathrm{K}$ were prepared and analyzed by a Rigaku X-ray diffractometer after air-drying and glycerol-solvation for the Mg-saturated clay, and after air-drying and heating at $300^{\circ} \mathrm{C}$ and $550^{\circ} \mathrm{C}$ for the $\mathrm{K}$-saturated clay. Relative mineral contents in the clay fraction were semi-quantitatively estimated on the basis of the XRD peak intensities. The relative proportions of the minerals of a sample were normalized to $100 \%$ under assumption of the same pro-

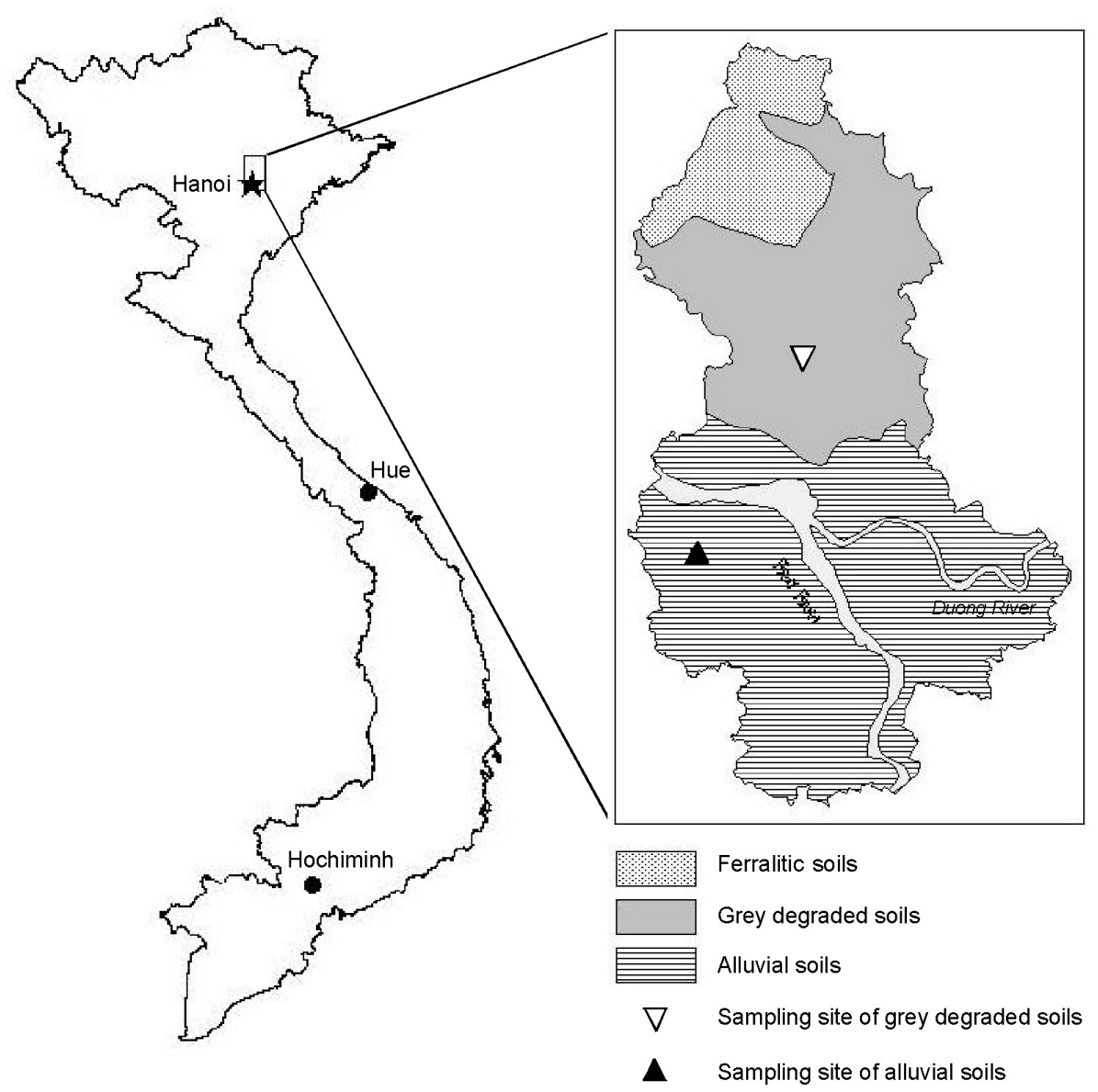

Fig. 1. Locations of sampling sites on the soil map of Vietnam. 
portionality between the peak intensity and the content for each mineral.

\section{Batch adsorption test}

The batch equilibrium test was used for determination of the heavy metal adsorption isotherm of a soil. Seven concentration levels of $\mathrm{Cu}, \mathrm{Pb}$ and $\mathrm{Zn}$ at 50, 100, $250,500,1000,1500$ and $2000 \mathrm{mg} / \mathrm{L}$, and 6 concentration levels of $\mathrm{Cd}$ at 5, 10, 20, 50, 70 and $100 \mathrm{mg} / \mathrm{L}$ were prepared from the respective metal nitrate salts. Seven or six sets of $2.00 \mathrm{~g}$ air-dry soil were exactly weighed into a $50-\mathrm{mL}$ centrifuge tube and mixed with $20 \mathrm{~mL}$ of each of the above heavy metal solutions. The mixture was shaken for $24 \mathrm{~h}$ at room temperature of $25^{\circ} \mathrm{C}$ for equilibration and then centrifuged at 2,000 rpm for $15 \mathrm{~min}$ to separate the supernatant solution from soil. The equilibrium metal concentration in solution was determined by an atomic absorption spectrophotometer. The experiment was done in duplicate to ensure the accuracy of determination.

The amount of heavy metal adsorbed was calculated by the equation:

$$
q_{a}=\frac{\left(C_{i}-C_{f}\right) V}{m}
$$

where $q_{a}$ is the amount of metal adsorbed per unit mass of soil $(\mathrm{mg} / \mathrm{kg}) ; \mathrm{C}_{\mathrm{i}}$ is the initial concentration $(\mathrm{mg} / \mathrm{L})$ of the metal nitrate solution before batch test; $\mathrm{C}_{\mathrm{f}}$ is the equilibrium (final) metal concentration $(\mathrm{mg} / \mathrm{L})$ in solution after batch test; $\mathrm{V}$ is the volume of the metal nitrate solution $(\mathrm{mL})$; and $\mathrm{m}$ is the mass of soil (g) used in the batch test.

The calculated $\mathrm{q}_{\mathrm{a}}$ values were large. Therefore, in the present study, we divided left- and right-hand sides of the equation by 10 for a better datum exhibition. Because the ratio of $\mathrm{V}$ to $\mathrm{m}$ was 10:1, the above equation can be written in a simpler form:

$$
\mathrm{q}_{\mathrm{a}} 10^{-1}=\mathrm{C}_{\mathrm{i}}-\mathrm{C}_{\mathrm{f}}
$$

\section{RESULTS AND DISCUSSION}

\section{Some chemical and physical properties of the soils}

The $\mathrm{pH}$, organic matter and free iron oxides contents, particle-size distribution and texture of the alluvial soil and grey degraded soil are given in Table 1 . The alluvial soil had a slightly alkaline reaction ( $\mathrm{pH} 7.7$ ), medium organic matter content $(17.2 \mathrm{~g} / \mathrm{kg})$, high free iron oxides content $(43.3 \mathrm{~g} / \mathrm{kg})$, and a texture of clay loam with the clay, silt, fine sand and coarse sand contents of $17.2,27.5,54.5$ and $0.8 \%$, respectively. Those properties have been well characterized for Eutric Fluvisols of the Red River system as reported by Nguyen et al. (2005) and Nguyen and Egashira (2005a). For the grey degraded soil, the pH value (5.7) was in an acid range and the organic matter content $(13.8 \mathrm{~g} / \mathrm{kg})$ was lower than that of the alluvial soil. Especially, the free iron oxides content $(4.3 \mathrm{~g} / \mathrm{kg})$ was very low resulting in the grey color, a morphological characteristic of grey degraded soils. Another characteristic of the grey degraded soil was a coarse surface texture of sandy loam with the low clay (6.7\%) and silt (15.7\%) contents and the high fine sand $(74.1 \%)$ content. This is considered a corollary of soil degradation (NISF and DSTPQ, MARD, 2002).

\section{Clay mineralogy of the soils}

The relative mineral contents in the $<2 \mu$ m clay fraction of the alluvial soil and grey degraded soil are shown in Table 2. Mica (40\%) and kaolinite (24\%) were predominant clay minerals of the alluvial soil accompanied with minor amounts of chlorite (8\%), vermiculite (12\%) and smectite (2\%). Minerals other than layer silicate minerals such as goethite, gibbsite, quartz and feldspars were detected with a range from trace to less than $10 \%$ in the clay fraction. The clay mineral composition of the alluvial soil in the present study was in accordance with that of alluvial soils from the Red River system in reference to the previous study (Nguyen and Egashira, 2005b).

The grey degraded soil had the lower mica (14\%) and chlorite (3\%) while higher kaolinite (36\%) contents

\begin{tabular}{|c|c|c|c|c|c|c|c|c|}
\hline \multirow[b]{2}{*}{ Soil } & \multirow{2}{*}{$\mathrm{pH}$} & \multirow{2}{*}{$\begin{array}{l}\text { Organic matter } \\
(\mathrm{g} / \mathrm{kg})\end{array}$} & \multirow{2}{*}{$\begin{array}{c}\text { Free iron } \\
\text { oxides }(\mathrm{g} / \mathrm{kg})\end{array}$} & \multicolumn{4}{|c|}{ Particle-size distribution (\%) } & \multirow{2}{*}{$\begin{array}{l}\text { Soil texture } \\
\quad \text { (IUSS) }\end{array}$} \\
\hline & & & & $\begin{array}{c}\text { Clay } \\
(<2 \mu \mathrm{m})\end{array}$ & $\begin{array}{c}\text { Silt } \\
(2-20 \mu \mathrm{m})\end{array}$ & $\begin{array}{l}\text { Fine sand } \\
(20-200 \mu \mathrm{m})\end{array}$ & $\begin{array}{c}\text { Coarse sand } \\
(200-2,000 \mu \mathrm{m})\end{array}$ & \\
\hline \multirow{2}{*}{$\begin{array}{l}\text { Alluvial soil } \\
\text { Grey degraded soil }\end{array}$} & 7.7 & 17.2 & 43.3 & 17.2 & 27.5 & 54.5 & 0.8 & \multirow{2}{*}{$\begin{array}{l}\text { clay loam } \\
\text { sandy loam }\end{array}$} \\
\hline & 5.7 & 13.8 & 4.3 & 6.7 & 15.7 & 74.1 & 3.5 & \\
\hline
\end{tabular}

Table 1. The $\mathrm{pH}$, organic matter and free iron oxides contents, particle-size distribution and texture of the alluvial soil and grey degraded soil

Table 2. Approximate relative mineral contents (\%) in the $<2 \mu \mathrm{m}$ clay fraction of the alluvial soil and grey degraded soil

\begin{tabular}{lccccccccccccc}
\hline \multicolumn{1}{c}{ Soil } & Mc & Ch & Vt & St & Mx & Ch-Vt & Kt & Gt & Gb & Qr & Fd \\
\hline Alluvial soil & 40 & 8 & 12 & 2 & & & 24 & 2 & tr. & 9 & 3 \\
Grey degraded soil & 14 & 3 & & & 6 & 12 & 36 & tr. & tr. & 27 & 2 \\
\hline
\end{tabular}

Abbreviations: Mc, mica; Ch, chlorite; Vt, vermiculite; St, smectite; Mx, mica/vermiculite/smectite $\sim$ mica/smectite mixed-layer mineral;

Ch-Vt, chlorite-vermiculite intergrade; Kt, kaolinite; Gt, goethite; Gb, gibbsite; Qr, quartz; Fd, feldspars. 
than did the alluvial soil, and contained some amounts of the mica/vermiculite/smectite mica/smectite mixedlayer mineral (6\%). Vermiculite was not detected in the grey degraded soil. Instead, chlorite-vermiculite intergrade was present with the content (12\%) corresponding to that of vermiculite in the alluvial soil. This suggested that chlorite-vermiculite intergrade would be a chloritization product of vermiculite. As for the minerals other than layer silicate minerals, the contents of goethite, gibbsite and feldspars in the grey degraded soil were comparable with those in the alluvial soil, whereas the quartz content (27\%) was higher by three times for the former than for the latter. The lower mica and higher kaolinite and quartz contents in the grey degraded

Table 3. The initial $\left(\mathrm{C}_{\mathrm{i}}, \mathrm{mg} / \mathrm{L}\right)$ and equilibrium $\left(\mathrm{C}_{\mathrm{f}}, \mathrm{mg} / \mathrm{L}\right)$ concentrations of the metal nitrate solution, and the amount of metal adsorbed per unit mass of soil $\left(\mathrm{q}_{\mathrm{a}} 10^{-1}, \mathrm{mg} / \mathrm{kg}\right)$ in the batch adsorption test

\begin{tabular}{|c|c|c|c|c|c|c|c|c|c|c|}
\hline \multirow{2}{*}{ Soil } & \multirow{2}{*}{$\mathrm{C}_{\mathrm{i}}$} & \multicolumn{2}{|c|}{$\mathrm{Cu}$} & \multicolumn{2}{|c|}{$\mathrm{Pb}$} & \multicolumn{2}{|c|}{$\mathrm{Zn}$} & \multicolumn{3}{|c|}{$\mathrm{Cd}$} \\
\hline & & $\mathrm{C}_{\mathrm{f}}$ & $\mathrm{q}_{\mathrm{a}} 10^{-1}$ & $\mathrm{C}_{\mathrm{f}}$ & $\mathrm{q}_{\mathrm{a}} 10^{-1}$ & $\mathrm{C}_{\mathrm{f}}$ & $\mathrm{q}_{\mathrm{a}} 10^{-1}$ & $\mathrm{C}_{\mathrm{i}}$ & $\mathrm{C}_{\mathrm{f}}$ & $\mathrm{q}_{\mathrm{a}} 10^{-1}$ \\
\hline \multirow[t]{7}{*}{ Alluvial soil } & 50 & 0.3 & 49.7 & 0.0 & 50.0 & 0.4 & 49.6 & 5 & 0.0 & 5.0 \\
\hline & 100 & 0.7 & 99.3 & 0.0 & 100.0 & 5.5 & 94.5 & 10 & 0.0 & 10.0 \\
\hline & 250 & 10.5 & 239.5 & 0.0 & 250.0 & 82.5 & 167.5 & 20 & 0.1 & 19.9 \\
\hline & 500 & 166.5 & 333.5 & 0.5 & 499.5 & 223.7 & 276.3 & 50 & 0.8 & 49.2 \\
\hline & 1000 & 584.9 & 415.1 & 25.0 & 975.0 & 658.7 & 341.3 & 70 & 1.7 & 68.3 \\
\hline & 1500 & 1066.5 & 433.5 & 209.9 & 1290.1 & 1121.6 & 378.4 & 100 & 3.9 & 96.1 \\
\hline & 2000 & 1552.6 & 447.4 & 540.3 & 1459.7 & 1609.9 & 390.1 & & & \\
\hline \multirow[t]{7}{*}{ Grey degraded soil } & 50 & 11.7 & 38.3 & 1.3 & 48.7 & 16.9 & 33.1 & 5 & 0.2 & 4.8 \\
\hline & 100 & 48.4 & 51.6 & 1.4 & 98.6 & 51.6 & 48.4 & 10 & 0.5 & 9.5 \\
\hline & 250 & 196.0 & 54.0 & 33.0 & 217.0 & 186.8 & 63.2 & 20 & 1.5 & 18.5 \\
\hline & 500 & 444.3 & 55.7 & 243.1 & 256.9 & 427.1 & 72.9 & 50 & 9.4 & 40.6 \\
\hline & 1000 & 943.3 & 56.7 & 734.4 & 265.6 & 905.6 & 94.4 & 70 & 18.2 & 51.8 \\
\hline & 1500 & 1438.5 & 61.5 & 1220.5 & 279.5 & 1400.4 & 99.6 & 100 & 35.1 & 64.9 \\
\hline & 2000 & 1932.9 & 67.1 & 1760.8 & 239.2 & 1894.7 & 105.3 & & & \\
\hline
\end{tabular}
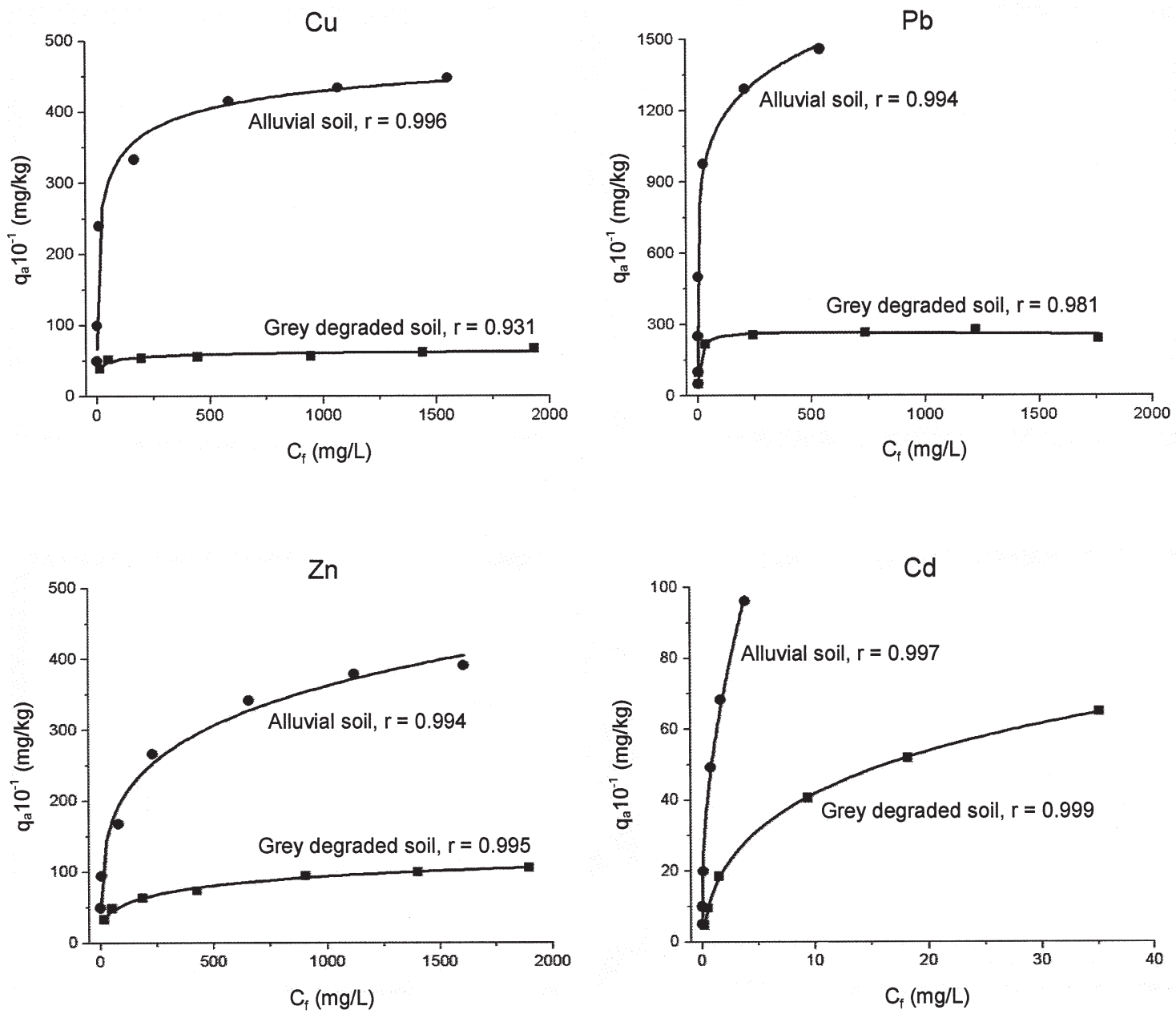

Fig. 2. Comparison of adsorption isotherms of $\mathrm{Cu}, \mathrm{Pb}, \mathrm{Zn}$ and $\mathrm{Cd}$ between the alluvial soil and grey degraded soil. The amount of heavy metals adsorbed $\left(\mathrm{q}_{\mathrm{a}} 10^{-1}\right)$ is plotted against the equilibrium concentration $\left(\mathrm{C}_{\mathrm{f}}\right)$ by using the Freudlich model. 
soil have been reported by Do et al. (2002), who attributed it to decomposition of layer silicate minerals due to ferrolysis.

\section{Adsorption capacity of heavy metals}

Parameters from the batch adsorption test including the initial $\left(\mathrm{C}_{\mathrm{i}}\right)$ and equilibrium $\left(\mathrm{C}_{\mathrm{f}}\right)$ concentrations of the metal nitrate solution, and the amount of metal adsorbed per unit mass of soil $\left(\mathrm{q}_{\mathrm{a}} 10^{-1}\right)$ are given in Table 3. Adsorption isotherms of the respective heavy metals $(\mathrm{Cu}, \mathrm{Pb}, \mathrm{Zn}$, and $\mathrm{Cd}$ ) are plotted using OriginPro 7.5 software for the alluvial soil and grey degraded soil in Fig. 2. The relationship between $\mathrm{q}_{\mathrm{a}} 10^{-1}$ and $\mathrm{C}_{\mathrm{f}}$ was well fitted to the Freudlich model with a very high correlation coefficient. In all cases, the adsorbed amount of any heavy metal at the same initial concentration was distinctly higher for the alluvial soil than for the grey degraded soil, suggesting the large adsorption capacity of heavy metals of the former in comparison with the latter. Variation in the adsorbed amount of heavy metals between the two soils was small at the low initial concentration levels but became larger at the higher initial concentration levels. This variation was dependent on the heavy metals, and was largest for $\mathrm{Pb}$, followed by $\mathrm{Cu}$ and $\mathrm{Zn}$, and smallest for $\mathrm{Cd}$.

Figure 3 shows adsorption isotherms of $\mathrm{Cu}, \mathrm{Pb}$ and Zn for the alluvial soil and grey degraded soil. The adsorption isotherm of $\mathrm{Cd}$ was not included here, because initial concentrations used in the batch adsorption test for $\mathrm{Cd}$ were different from those used for $\mathrm{Cu}$, $\mathrm{Pb}$ and $\mathrm{Zn}$. As shown in Fig. 3, the adsorption capacity within a soil was varied with heavy metals. In case of the alluvial soil, the adsorption rate or the ratio of $\mathrm{q}_{\mathrm{a}} 10^{-1}$ to $\mathrm{C}_{\mathrm{i}}$ (data not shown) was kept at a high value while the equilibrium concentration remained in a very low level at initial concentrations between 50 and $100 \mathrm{mg} / \mathrm{L}$ for $\mathrm{Zn}$, between 50 and $250 \mathrm{mg} / \mathrm{L}$ for $\mathrm{Cu}$, and between 50 and to $1,000 \mathrm{mg} / \mathrm{L}$ for $\mathrm{Pb}$. It meant that almost all amounts of added heavy metal were adsorbed by soil, and the adsorption capacity of heavy metals decreased in the sequence of $\mathrm{Pb}>>\mathrm{Cu}>\mathrm{Zn}$. At initial concentra- tions over the above ranges, the adsorption rate was quickly reduced and hence the adsorbed amount of heavy metals became gradually constant. In the grey degraded soil, however, the adsorption rate was quickly reduced as exceeding initial concentrations of $50 \mathrm{mg} / \mathrm{L}$ for $\mathrm{Cu}$ and $\mathrm{Zn}$ and of $250 \mathrm{mg} / \mathrm{L}$ for $\mathrm{Pb}$. The reduction in the adsorption rate was greater for $\mathrm{Cu}$ than for $\mathrm{Zn}$, leading to the higher adsorbed amount for the latter than for the former at the initial concentration of $2,000 \mathrm{mg} / \mathrm{L}$. Therefore, the adsorption capacity of heavy metals in the grey degraded soil followed the order of $\mathrm{Pb}$ $>>\mathrm{Zn}>\mathrm{Cu}$.

In case of $\mathrm{Cd}$, because the initial concentration range used in the batch adsorption test was different from that for $\mathrm{Cu}, \mathrm{Pb}$ and $\mathrm{Zn}$, direct comparison was difficult on the adsorption capacity with them. However, based on the comparison on the adsorbed amount with $\mathrm{Cu}, \mathrm{Pb}$ and $\mathrm{Zn}$ at initial concentrations ranging from 50 to $100 \mathrm{mg} / \mathrm{L}$, the adsorption capacity of Cd was estimated to be equivalent to that of $\mathrm{Zn}$ for the alluvial soil, and smaller than that of $\mathrm{Pb}$ but larger than those of $\mathrm{Zn}$ and $\mathrm{Cu}$ for the grey degraded soil.

\section{Adsorption capacity of heavy metals in relation to heavy metal attributes and composition of adsorb- ing soil components}

Among soil components, organic matter, free iron oxides, and clay minerals are considered important adsorbents for heavy metals (Bradl, 2004). The content of active 2:1-type silicate minerals in the clay faction was higher for the alluvial soil (62\% as a total of mica, chlorite, vermiculite and smectite) than for the grey degraded soil (35\% as a total of mica, chlorite, the mica/vermiculite/smectite $\sim$ mica/smectite mixed-layer mineral and chlorite-vermiculite intergrade). The organic matter, free iron oxides and clay contents were also higher for the alluvial soil than for the grey degraded soil. As a result, the adsorption capacity of heavy metals $(\mathrm{Cu}, \mathrm{Pb}, \mathrm{Zn}$ and $\mathrm{Cd}$ ) of the former was distinctly larger than that of the latter, as mentioned in the above. In addition, the lower $\mathrm{pH}$ of the grey degraded
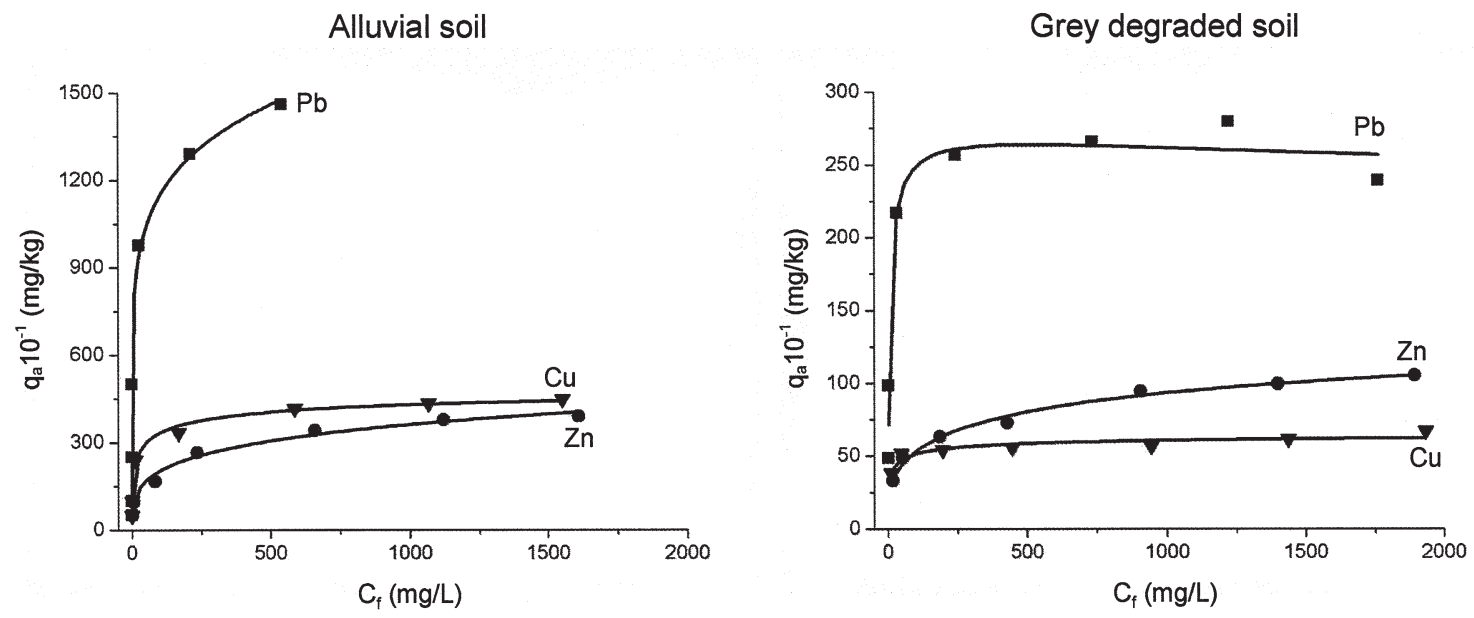

Fig. 3. Adsorption isotherms of $\mathrm{Cu}, \mathrm{Pb}$ and $\mathrm{Zn}$ in the alluvial soil and grey degraded soil. The amount of heavy metals adsorbed ( $\left.\mathrm{q}_{\mathrm{a}} 10^{-1}\right)$ is plotted against the equilibrium concentration $\left(\mathrm{C}_{\mathrm{f}}\right)$ by using the Freudlich model. 
soil would increase mobility of heavy metal ions.

Within a soil, the adsorption capacity of heavy metals followed the order of $\mathrm{Pb}>>\mathrm{Cu}>\mathrm{Zn}$ for the alluvial soil and of $\mathrm{Pb}>>\mathrm{Zn}>\mathrm{Cu}$ for the grey degraded soil. This would be related to the attributes of heavy metals and composition of adsorbing soil components. It has been recognized that the adsorption maxima of heavy metals by soil components such as organic matter, free iron oxides and clay minerals were often higher for $\mathrm{Pb}$ than for $\mathrm{Cu}$ and $\mathrm{Zn}$ (Helios et al., 1995; Veeresh et al., 2003). This might be a reason for the largest adsorption capacity of $\mathrm{Pb}$ observed in the soils of the present study.

In case of $\mathrm{Cu}$, the adsorption maxima among soil components decreased in the order of organic matter $>$ free iron oxides $>$ clay minerals (Bradl, 2004), whereas in case of $\mathrm{Zn}$, free iron oxides did not much contribute to its adsorption. Therefore, the adsorption capacity of $\mathrm{Cu}$ over Zn observed in the alluvial soil could be considered to be due to the high free iron oxides content of the soil. The order in the adsorption capacity of heavy metals observed in the alluvial soil of the present study has been found in many types of soil (Welp and Brümmer, 1999; Veeresh et al., 2003).

For the grey degraded soil, the low organic matter and very low free iron oxides contents probably restricted the adsorption capacity of $\mathrm{Cu}$. Active 2:1-type silicate minerals in the clay faction of the grey degraded soil were present with considerable amounts but they adsorbed $\mathrm{Cu}$ less strongly than organic matter and free iron oxides did. However, active 2:1-type silicate minerals exhibited a large fixing capacity for $\mathrm{Zn}$ (Bradl, 2004). For this reason, the adsorption capacity of $\mathrm{Zn}$ observed in the grey degraded soil was greater than that of $\mathrm{Cu}$.

\section{CONCLUSIONS}

Two surface soil samples collected in Hanoi, Vietnam well represented alluvial soils and grey degraded soils in the area, since their chemical, physical and clay mineralogical properties were in accordance with those reported by previous studies for the same soil types. The alluvial soil had the high organic matter, free iron oxides, clay and active 2:1-type silicate minerals contents, and high $\mathrm{pH}$ value in comparison with those of the grey degraded soil. As a consequence, the adsorption capacity of heavy metals ( $\mathrm{Cu}, \mathrm{Pb}, \mathrm{Zn}$ and $\mathrm{Cd}$ ) was distinctly larger for the alluvial soil than for the grey degraded soil. Within a soil the adsorption capacity was related to the attributes of heavy metals and composition of adsorbing soil components. It decreased in the sequence of $\mathrm{Pb}>>\mathrm{Cu}>\mathrm{Zn}$ for the alluvial soil and of $\mathrm{Pb}>>\mathrm{Zn}>\mathrm{Cu}$ for the grey degraded soil.

\section{ACKNOWLEDGEMENTS}

The first author would like to express her sincere thanks to Soils and Fertilizers Institute and Vietnam Academy of Agricultural Sciences, Hanoi, Vietnam for permission of study-leave to Faculty of Agriculture, Kyushu University, Japan, where the present work was done.

\section{REFERENCES}

Bradl, H. B. 2004 Adsorption of heavy metal ions on soils and soil constituents. Journal of Colloid and Interface Science, 277: $1-18$

Do Nguyen Hai, Trinh Quang Huy and K. Egashira 2002 Mineralogy and clay degradation in grey degraded soils of Vietnam. Clay Science, 11: 535-547

Egashira K., A. Kaieda, and Do Nguyen Hai 2002 General chemical fertility and chemical processes of grey degraded soils as a problem soil in Vietnam. Journal of the Faculty of Agriculture, Kyushu University, 47: 437-445

Ha Manh Thang and Pham Quang Ha 2005 The intensity effect of heavy metal concentration in soil and leaf vegetable in peri-urban of Hanoi. Vietnam Soil Science, 23: 149-152 (in Vietnamese)

Helios R. E., W. Calmano and A. Breeger 1995 Heavy metals sorption/desorption on competing clay minerals; an experimental study. Applied Clay Science, 9: 369-381

Ho Thi Lam Tra and K. Egashira 2000 Heavy metal characterization of river sediment in Hanoi, Vietnam. Communication in Soil Science and Plant Analysis, 31: 2901-2916

National Institute for Soils and Fertilizers (NISF) and Department of Science, Technology and Product Quality (DSTPQ), Ministry of Agriculture and Rural Development (MARD) 2002 The Basic Information of Main Soil Units of Vietnam. Thegioi Publishers, Hanoi (Vietnam)

Nguyen Manh Khai, Pham Quang Ha and I. Oborn 2006 Element balance as a tool to assess the potential risk contamination for soil environment - A case study of heavy metal balance in peri-urban agriculture of Hanoi City. Vietnam Soil Science, 26: 112-118 (in Vietnamese)

Nguyen Quang Hai, Ho Thi Lam Tra, A. Z. M. Moslehuddin and K. Egashira 2006 Clay mineralogy of alluvial soils and grey degraded soils derived from the same river sediment in the Red River Delta, northern Vietnam. Clay Science, 13: 101-105

Nguyen Quang Hai and K. Egashira 2005a Particle-size distribution and free iron oxides of alluvial soils from different agro-ecological regions in Vietnam. Journal of the Faculty of Agriculture, Kyushu University, 50: 243-254

Nguyen Quang Hai and K. Egashira 2005b Clay mineralogical composition of alluvial soils from different river systems/agroecological regions in Vietnam in reference to origin, regional distribution and soil quality. Clay Science, 12: 349-360

Nguyen Quang Hai, K. Egashira, Pham Quang Ha and Ho Quang Duc 2005 Selected chemical properties of alluvial soils in Vietnam. Journal of the Faculty of Agriculture, Kyushu University, 50: 233-242

Nguyen Thi Lan Huong 2006 Heavy metal concentration of soil at industrial zone of Hanoi suburb. Vietnam Soil Science, 26: 129-131 (in Vietnamese)

Nguyen Xuan Hai and Duong Tu Oanh 2004 Contaminants in water and soil of Taytuu Commune. Vietnam Soil Science, 20: 124-128 (in Vietnamese)

Veeresh, H., S. Tripathy, D. Chaudhuri, B. R. Hart and M. A. Powell 2003 Competitive adsorption behavior of selected heavy metals in three soil types of India amended with fly ash and sewage sludge. Environmental Geology, 44: 363-370

Vietnam Soil Science Society (VSSS) 1996 The Soil of Vietnam. Agricultural Publishing House, Hanoi (Vietnam) (in Vietnamese)

Welp, G. and G. W. Brümmer 1999 Adsorption and solubility of ten metals in soil samples of different compositions. Journal of Plant Nutrition and Soil Science, 162: 155-161 